\title{
Immunoprotective Capability of Somatic Hybrid Cells in Comparison with Parental Tumor Gells Maintained In Vitro
}

\author{
Yutaka Mizushima and Edward P. Cohen \\ Department of Microbiology and Immunology, University \\ of Illinois at Chicago, Illinois 60680, USA
}

\begin{abstract}
Mizushima, Y. and Cohen, E.P. Immunoprotective Capability of Somatic Hybrid Cells in Comparison with Parental Tumor Cells Maintained In Vitro. Tohoku J. exp. Med., 1985, 145 (4), 447-453 — The immunogenicity of Xirradiated hybrid cells derived from fusion of ASL-1 leukemia (A origin) and LM $\left(\mathrm{TK}^{-}\right.$) fibroblasts (C3H origin) was compared to $\mathrm{X}$-irradiated parental ASL-1 leukemia cells maintained in vivo (V-ASL-1) and to X-irradiated ASL-1 leukemia cells maintained in vitro (C-ASL-1). Immunization with hybrid cells induced transplantation resistance against tumor rechallenge with V-ASL-1 more effectively than did immunization with V-ASL-1 tumor cells. Immunization with X-irradiated C-ASL-1 cells produced the same, or slightly stronger level of transplantation resistance than that with $\mathrm{X}$-irradiated hybrid cells. These findings were observed both in $\mathrm{A} / \mathrm{J}$ and in $(\mathrm{C} 3 \mathrm{H} / \mathrm{HeJ} \times \mathrm{A} / \mathrm{J}) \mathrm{F}_{1}$ mice. These results raise a question about whether the apparent increased immunogenicity of hybrid cells is due to a result of cell fusion or a result of their growth in vitro. munogenicity; somatic hybrid cells; in vitro cultivation
\end{abstract}

The immunogenicity of some tumors is very weak or unrecognizable. In these cases it has been difficult to prove that the host can elicite an effective antitumor immune response to the tumor. If antigens on tumor cells could be amplified or exposed, it might be possible to boost the host defenses against cancer. Several different approaches have been made to increase the immunogenicity of tumor cells. These include, chemical modifications of tumor cells, viral xenogenization, or cell hybridization (Kobayashi et al. 1970 ; Prager et al. 1974 ; Kataoka et al. 1977; Klein and Klein 1979; Klein 1979; Takatsu et al. 1980). The ultimate purpose behind all of these studies has been to increase the immunogenicity of tumor cells so that an effective antitumor immune response can be stimulated in the tumor-bearing host.

Previous studies from our laboratory (Liang and Cohen 1976, 1977a and b)

Received September 17, 1984 ; accepted for publication November 30, 1984.

Supported by HHS grant number CA 27579-04 awarded by the National Cancer Institute, DHHS, USA. 
have shown that specific transplantation resistance to parental ASL-1 leukemia (A origin) could be induced in $(\mathrm{C} 3 \mathrm{H} / \mathrm{HeJ} \times \mathrm{A} / \mathrm{J}) \mathrm{F}_{1}$ mice by immunization with viable somatic hybrid of ASL-1 and $\mathrm{LM}\left(\mathrm{TK}^{-}\right)(\mathrm{C} 3 \mathrm{H}$ origin) cells. Significant resistance could not be induced by immunization with mitomycin C-treated in vivo passaged ASL- 1 tumor cells (V-ASL-1) in A/J mice. The studies reported in this article were undertaken to further determine if the immunogenicity of hybrid cells is qualitatively greater than that of parental tumor cells. In an attempt to obtain an objective comparison of the immunogenicity of the different cell types the immunoprotective capability of hybrid and parental tumor cells, was evaluated using an $\mathrm{X}$-irradiated tumor cell inoculum to immunize the animals.

\section{Material and Methods}

Animals. A/J and $(\mathrm{C} 3 \mathrm{H} / \mathrm{HeJ} \times \mathrm{A} / \mathrm{J}) \mathrm{F}_{1}$ mice, 6-8 weeks old, were obtained from the Jackson Laboratory (Bar Harbor, Maine, U.S.A.).

Cells. ASL-1 is a spontaneously occurring leukemia of A strain. In vivo ASL-1 cells (V-ASL-1) are maintained in A/J mice by weekly i.p. passage of $5 \times 10^{6}$ tumor cells which are obtained from the spleens of terminally ill mice. Greater than $90 \%$ of the spleen cells were neoplastic by morphologic criteria at the time of cell transfer. A long term culture

TABLE 1. Some properties of $V-A S L-1, C-A S L-1$ and hybrid cells

\begin{tabular}{|c|c|c|c|c|}
\hline & \multirow{2}{*}{ Characteristic } & \multicolumn{3}{|c|}{ Cells } \\
\hline & & V-ASL-1 & C-ASL-1 & LA \\
\hline \multirow[t]{4}{*}{ 1) } & $H-2$ antigens & & & \\
\hline & $\mathrm{H}-2^{\mathrm{a}}$ antigens & $\mathrm{m}^{\mathrm{a}}$ & +m+ & m \\
\hline & $\mathrm{H}-2^{\mathrm{k}}$ antigens & - & - & m+m \\
\hline & TL antigens & H & m+1 & H \\
\hline \multirow[t]{3}{*}{ 2) } & Tumorigenicity & & & \\
\hline & $5 \times 10^{3}$ ip in $\mathrm{A} / \mathrm{J}$ & $4 / 4(12.8)^{\mathrm{b}}$ & $4 / 4(15.0)$ & $\begin{array}{l}\text { Non-tumorigenic } \\
\text { in } A / J \text { and } F_{1}\end{array}$ \\
\hline & $5 \times 10^{6}$ ip in $\mathrm{A} / \mathrm{J}$ & $4 / 4(6.5)$ & $4 / 4(10.0)$ & $\begin{array}{l}\text { Non-tumorigenic } \\
\text { in } \mathrm{A} / \mathrm{J} \text { and } \mathrm{F}_{1}\end{array}$ \\
\hline 3) & Type of growth in vitro & & Suspension & Adherent \\
\hline 4) & NK sensitivity ${ }^{\mathrm{c}}$ & Insensitive & Insensitive & $\mathrm{NT}^{\mathrm{e}}$ \\
\hline \multirow[t]{3}{*}{ 5) } & Antigenic Modulation ${ }^{\mathrm{d}}$ & & & \\
\hline & with $\bar{a}$-TL serum & NT & Yes & Yes \\
\hline & with $\bar{a}-\mathrm{H}-2^{\mathrm{a}}$ serum & NT & Yes & Yes \\
\hline
\end{tabular}

a. Positive cells $(\%)$ by indirect immunofluorescence. HWt , >80\%; H, 80\%-60\%; H, 60\%-40\%; - , <10\%.

b. Lethal growth (MSD) in normal adult mice.

c. 4 hour $-{ }^{51} \mathrm{Cr}$ release assay was performed with normal spleen cells from $\mathrm{A} / \mathrm{J}$, $\mathrm{BALB} / \mathrm{c}$, and $\mathrm{C} 3 \mathrm{H} / \mathrm{HeJ}$.

d. Cells were incubated with antiserum at $37^{\circ} \mathrm{C}$ for $30-120 \mathrm{~min}$., and then washed and stained with fluorescein-labeled rabbit anti-mouse Ig (Dakopatts, Denmark).

e. $\quad \mathrm{NT}=$ Not tested. 
subline of the ASL-1 was established (C-ASL-1). Cultures which were 3-6 months old were used in this study. $\mathrm{LM}\left(\mathrm{TK}^{-}\right)$is a thymidine kinase-deficient subline of $\mathrm{LM}$ cells $(\mathrm{C} 3 \mathrm{H}$ origin). Hybrid cells were obtained by the fusion of LM ( $\mathrm{TK}^{-}$) and V-ASL-1 cells using polyethylene glycol (PEG 1000), and selection was done with HAT medium $\left(1 \times 10^{-4} \mathrm{M}\right.$ hypoxanthine, $4 \times 10^{-7} \mathrm{M}$ aminopterin, $1.6 \times 10^{-5} \mathrm{M}$ thymidine). LM $\left(\mathrm{TK}^{-}\right) \times \mathrm{ASL}-1$ hybrid cells (LA) used in this study were prepared approximately 36 months prior to the initiation of these studies. The clonal isolate of the hybrid cells was stable and it possessed $74 \pm 8$ chromosomes including marker chromosomes of each parental source. C-ASL-1, LM $\left(\mathrm{TK}^{-}\right)$and LA cells were maintained in RPMI-1640 supplemented with heat-inactivated fetal bovine serum (10\%) (Hyclone, Utah, U.S.A.), L-glutamine (2 mM), penicillin (100 U/ $\mathrm{ml})$, streptomycin $(100 \mu \mathrm{g} / \mathrm{ml})$, fungizon $(0.25 \mu \mathrm{g} / \mathrm{ml})$, 2-mercaptoethanol $\left(5 \times 10^{-5} \mathrm{M}\right)$, and Hepes buffer $(20 \mathrm{mM})$. As a wash medium, Eagle's minimum essential medium (MEM) (Gibco, NY, U.S.A.) supplemented only with antibiotics and Hepes buffer solution was used. Both $\mathrm{LM}_{\left(\mathrm{TK}^{-}\right)}$) and the hybrid cells have adherent properties and therefore it was necessary to incubate cultural dishes with $0.6 \mathrm{mM}$ EDTA in PBS to remove the cells from plastic flasks. Some of the properties of V-ASL-1, C-ASL-1, and the hybrid cells are summarized in Table 1.

Irradiation of tumor cells. Cells suspended in MEM were irradiated 7,000 rads at 90 rads/min. with a Cobalt-60 apparatus standardized before use.

Statistical analysis. The significant differences in mean survival time, and in lethal rate were tested by the Student's $t$-test and Fisher's exact probability test, respectively.

\section{RESUlts}

Immunoprotective capability of hybrid cells in $A / J$ and $(C 3 H / H e J \times A / J) F_{1}$ mice

Immunoprotective capability of X-irradiated hybrid cells (LA) was first compared to X-irradiated ASL-1 cells maintained in vivo (V-ASL-1). Both cells were. irradiated and inoculated i.p. into $\mathrm{A} / \mathrm{J}$ mice, and then all animals were

TABLE 2. Comparison of immunoprotective capability between hybrid cells and $V$ $A S L-1$ leukemia cells in $A / J$ mice

\begin{tabular}{|c|c|c|c|c|}
\hline Expt & $\begin{array}{l}\text { Immunization }^{\mathrm{a}} \\
\text { with }\end{array}$ & $\begin{array}{l}\text { No. of cells } \\
\text { challenged }\end{array}$ & $\begin{array}{l}\text { Lethal } \\
\text { growth }\end{array}$ & $\mathrm{MSD}_{ \pm \text {s.D. }}{ }^{\mathrm{b}}$ \\
\hline Irrad. & LA $1 \times 10^{7}$ i.p. once & $4 \times 10^{4} \mathrm{sc}$ & $12 / 13$ & $16.8 \pm 7.7^{\mathrm{c}}$ \\
\hline Irrad. & V-ASL-1 $1 \times 10^{7}$ i.p. once & $4 \times 10^{4} \mathrm{sc}$ & $12 / 12$ & $12.6 \pm 2.1$ \\
\hline None & & $4 \times 10^{4} \mathrm{sc}$ & $12 / 12$ & $11.6 \pm 0.6$ \\
\hline II Irrad. & LA $5 \times 10^{6}$ i.p. twice & $1 \times 10^{4}$ i.p. & $10 / 10$ & $16.1 \pm 4.2^{\mathrm{c}, \mathrm{c}}$ \\
\hline Irrad. & V-ASL-1 $5 \times 10^{6}$ i.p. twice & $1 \times 10^{4}$ i.p. & $10 / 10$ & $11.8 \pm 0.7$ \\
\hline None & & $1 \times 10^{4}$ i.p. & $10 / 10$ & $11.5 \pm 1.2$ \\
\hline
\end{tabular}

a. In Exp. I, A/J mice were immunized i.p. once with $\mathrm{x}$-irradiated (7,000 rads) cells, and 10 days later V-ASL-1 cells $\left(4 \times 10^{4}\right)$ were challenged sc. In Exp. II, A/J mice were immunized i.p. twice with one week interval between injections. Two week after the 2 nd immunization V-ASL-1 cells $\left(1 \times 10^{4}\right)$ were challenged i.p.

b. Mean survival day. Only dead mice are included. Animals were observed for 60 days after tumor cell challenge.

c. $p<0.05$ compared with the nonimmunized group.

d. $p<0.05$ compared with the group having immunization with V-ASL-1 cells. 
TABLE 3. Comparison of immunoprotective capability among hybrid, $C-A S L-1$ and $V-A S L-1$ cells in $A$ / $J$ mice

\begin{tabular}{lll}
\hline $\begin{array}{c}\text { Immunization } \\
\text { with }\end{array}$ & $\begin{array}{c}\text { Lethal growth } \\
(\%)\end{array}$ & MSD \pm s.D. \\
\hline Viable LA & $18 / 24(75)$ & $15.6 \pm 4.4^{\mathrm{b}}$ \\
Irrad. LA & $23 / 24(96)$ & $17.3 \pm 5.1^{\mathrm{b}}$ \\
Irrad. C-ASL-1 & $16 / 24(67)^{\mathrm{b}}$ & $17.3 \pm 4.7^{\mathrm{b}}$ \\
Irrad. V-ASL-1 & $19 / 21(90)$ & $14.9 \pm 7.5$ \\
None & $23 / 24(96)$ & $12.3 \pm 1.3$ \\
\hline
\end{tabular}

a. A/J mice were immunized with tumor cells $\left(5 \times 10^{6}\right)$ i. p. twice with one week interval between injections. Two weeks after the 2nd immunization V-ASL-1 cells $\left(5 \times 10^{3}\right)$ were challenged i.p.

b. $\quad p<0.05$ compared with the nonimmunized group.

TABLE 4. Comparison of immunoprotective capability among hybrid, C-ASL-1 and $V-A S L-1$ cells in $(C 3 H / H e J \times A / J) F_{1}$ mice

\begin{tabular}{lccccc}
\hline \multirow{2}{*}{$\begin{array}{l}\text { Immunization }^{\mathrm{a}} \\
\text { with }\end{array}$} & \multicolumn{2}{c}{$2 \times 10^{3}$ i.p. } & & \multicolumn{2}{c}{$1 \times 10^{4}$ i.p. } \\
\cline { 2 - 3 } \cline { 5 - 6 } & $\begin{array}{c}\text { Lethal growth } \\
(\%)\end{array}$ & MSD \pm S.D. & & $\begin{array}{c}\text { Lethal growth } \\
(\%)\end{array}$ & MSD \pm S.D. \\
\hline Viable LA & $0 / 7(0)^{\mathrm{b}}$ & - & & $3 / 8(38)$ & $25.7 \pm 5.2^{\mathrm{b}}$ \\
Irrad. LA & $0 / 7(0)^{\mathrm{b}}$ & - & & $4 / 8(50)$ & $26.5 \pm 7.4^{\mathrm{b}}$ \\
Irrad. C-ASL-1 & $0 / 7(0)^{\mathrm{b}}$ & - & & $1 / 8(13)^{\mathrm{b}}$ & 21.0 \\
Irrad. V-ASL-1 & $6 / 7(86)$ & $16.3 \pm 2.9$ & & $5 / 8(63)$ & $12.3 \pm 2.2$ \\
None & $6 / 7(86)$ & $16.0 \pm 1.9$ & & $6 / 8(75)$ & $12.5 \pm 2.6$ \\
\hline
\end{tabular}

a. $\mathrm{F}_{1}$ mice were immunized with tumor cells $\left(5 \times 10^{6}\right)$ i.p. twice with one week interval between injections. Two weeks after the 2nd immunization, V-ASL-1 cells $\left(2 \times 10^{3}\right.$ or $\left.1 \times 10^{4}\right)$ were challenged i.p. Animals were observed for 45 days after tumor cell challenge.

b. $\quad p<0.05$ compared with the nonimmunized group.

challenged sc or i.p. with V-ASL-1 tumor cells according to the schedule described in the footnote of Table 2. No transplantation resistance was induced by immunization with V-ASL-1 cells whereas immunization with LA cells caused a significant prolongation of the MSD (Table 2). Experiments were undertaken to compare the immunoprotective capability of X-irradiated hybrid cells to that of $\mathrm{X}$-irradiated cultured ASL-1 tumor cells (C-ASL-1). As shown in Table 3, significant transplantation resistance was induced by immunization with either the hybrid cells or the C-ASL-1 cells, but immunization with X-irradiated V-ASL-1 did not cause any significant immunoprotection. The number of animals which died in irrad.-C-ASL-1-immunized group was significantly lower than that in irrad.-LA-immunized group (67\% vs $96 \%$ ). 
The immunoprotective capability of the different $\mathrm{X}$-irradiated cells was studied in histocompatible $\mathrm{F}_{1}\left(\mathrm{H}-2^{a / k}\right)$ mice (Table 4). Immunization with $\mathrm{X}$-irradiated V-ASL-1 cells did not induce any transplantation resistance to rechallenge with V-ASL-1 tumor cells. Significant transplantation immunity was observed by immunization with either X-irradiated hybrid or C-ASL-1 tumor cells or with viable LA cells.

\section{Discussion}

Many reports have been published concerning the possible increase in immunogenicity of hybrid cells (Watkins and Chen 1969; Parkman 1974; Liang and Cohen 1976, 1977a and b; Kim 1979; Klein and Klein 1979; Klein 1979 ; Yefenof et al. 1982 ; Toffaletti et al. 1983). In some studies the comparison of immunogenicity was performed between viable hybrid cells and irradiated parental tumor cells, while in other studies the comparison was performed between hybrid cells maintained in vitro and parental tumor cells maintained in vivo. Previous reports from our laboratory (Liang and Cohen 1976, 1977a and b) have shown that viable somatic hybrid cells could induce specific transplantation resistance although V-ASL-1 cells could not. In the present study, both hybrid cells (maintained in vitro) and parental tumor cells (maintained in vivo and in vitro) were lethally $\mathrm{x}$-irradiated, and their immunogenicity was studied in parental $\mathrm{A} / \mathrm{J}$ and in $\mathrm{F}_{1}$ mice. The results showed that the immunogenicity of $\mathrm{X}$-irradiated hybrid cells was higher than that of ASL-1 cells maintained in vivo (V-ASL-1), and that immunogenicity of $\mathrm{X}$-irradiated hybrid cells was not significantly higher than that of X-irradiated ASL-1 cells maintained in vitro (C-ASL-1). These results were observed in both $\mathrm{A} / \mathrm{J}\left(\mathrm{H}-2^{a}\right)$ and $\mathrm{F}_{1}\left(\mathrm{H}-2^{a / k}\right)$ mice, and this indirectly implies that $\mathrm{H}-2^{k}$ antigens which were present on the surface of hybrid cells are most likely not responsible for the apparent increase in immunogenicity. Viable hybrid cells were unexpectedly less immunogenic than irradiated C-ASL-1 cells. The loss of antitumor immunogenicity of somatic cell hybrid has been reported to occur with increasing subculture (Favre et al. 1975) and may reflect progressive chromosomal loss after prolonged in vitro growth. Better immunoprotection may have been obtained if younger cultures of the hybrid cells were employed. Anyway, our results raised a simple question about whether the increased immunogenicity of hybrid cells is due to a result of cell fusion or a result of their growth in vitro. Klein G and Klein E (1979) have reported that $\mathrm{X}$-irradiated in vitro somatic cell hybrids of YAC lymphoma and mouse fibroblasts induced a stronger transplantation resistance than did $\mathrm{X}$ irradiated parental in vivo YAC tumor cells. Klein's group (Devens et al. 1979 ; Galili et al. 1978) have shown that the YAC lymphoma changes aspects of its antigenic properties after in vitro cultivation. So our question above still remains to be solved. Further studies will be required to clarify this point.

Enhancement of tumor immunogenicity after in vitro cultivation has been 
reported with several tumors, e.g., Moloney virus-induced YAC lymphoma, chemically-induced MSC-10 squamous-cell carcinoma, and chemically-induced line 10 hepatocarcinoma (Morgan et al. 1970; Jamaski and Nettesheim 1977; Galili et al. 1978; Devens et al. 1979; Klein et al. 1981; Correll et al. 1983). Klein et al (1981) speculated that suppressogenic determinants expressed on tumor cells might be inactivated by in vitro cultivation. Correll et al. (1983) speculated fetal bovine serum which (FBS) bound to tumor cells might activate T-cell helper functions in vivo. In their studies, it is of interest that cells cultured in medium with $10 \%$ calf bovine serum, or $10 \%$ normal guinea pig serum, or reduced concentration of fetal bovine serum were less effective in inducing antitumor resistance. Conceivably the contamination of in vitro cultures by virus or mycoplasm may affect the immunogenicity of tumor cells. We have not investigated as yet the mechanism about the enhanced immunogenicity of C-ASL-1 cells after in vitro cultivation. However, if this is a generally observed phenomenon applicable to other systems, it seems to be very important from the view point of immunotherapy of cancer.

\section{Acknowledgments}

We thank Mrs. Varsha M. Kinariwalla for technical assistance, Dr. H. Terry Wepsic for his critical review, and Mrs. Corrine Arthur for typing this manuscript.

\section{References}

1) Correll, L.L., Nielsen, L.D., Kelleher, P.J., Harbell, J.W. \& Minden, P. (1983) Enhanced immunogenicity of line 10 guinea pig hepa tocarcinoma cells after culture. J. nat. Cancer Inst., 71, 1343-1346.

2) Devens, B., Schochot, L. \& Naor, D. (1979) Immune responses to weakly immunogeneic virally induced tumors. V. Short in vitro cultivation of YAC changes its antigenic properties. Immunology, 44, 442-453.

3) Favre, R., Carcassonne, Y. \& Meyer, G. (1975) Loss of anti-tumor immunogenicity of a somatic cell hybrid line with increasing subculture. Brit. J. Cancer, 32, 139-141.

4) Galili, N., Devens, B., Naor, D., Becker, S. \& Klein, E. (1978) Immune responses to weakly immunogenic virally induced tumors. I. Overcoming low responsiveness by priming mice with a syngeneic in vitro tumor line or allogenic cross-reactive tumor. Eur. J. Immunol., 8, 17-22.

5) Jamaski, R.J. \& Nettesheim, P. (1977) Increase in immunogenicity of a pulmonary squamouse-cell carcinoma, propagated in vitro. Int. J. Cancer, 20, 817-829.

6) Kataoka, T., Oh-hashi, F., Tsukagoshi, S. \& Sakurai, Y. (1977) Induction of resistance to L1210 leukemia In $\mathrm{BALB} / \mathrm{c} \times \mathrm{DBA} / 2 \mathrm{C} 4 \mathrm{~F}_{1}$ mice with $\mathrm{L} 1210$ cells treated with glutaraldehyde and concanavalin A. Cancer Res., 37, 964-968.

7) Kim, B.S. (1979) Tumor-specific immunity induced by somatic hybrids. II. Elicitation of enhanced immunity against the parent plasmacytoma. J. Immunol., 123, 739-744.

8) Klein, G. (1979) Antigenic expression in somatic hybrids and the use of cell fusion in tumor xenogenization. Gann Monogr Cancer Res., 23, 225-238.

9) Klein, G. \& Klein, E. (1979) Induction of tumor cell rejection in the low responsive YAC-1 lymphoma strain A host combination by immunization with somatic cell hybrids. Eur. J. Cancer, 15, 551-557. 
10) Klein, B.Y., Devens, B., Deutsch, O., Ahituv, A., Frenkel, S., Kobrin, B.J. \& Naor, D. (1981) Isolation of immunogeneic and suppressogenic determinants of nonimmunogenic YAC tumor and the change in its immunogenic repertoire after in vitro cultivation. Transplant. Proc., 8, 790-797.

11) Kobayashi, H., Sendo, F., Kaji, H., Shirai, T., Saito, H., Takeichi, N., Hosokawa, M. \& Kodama, T. (1970) Inhibition of transplanted rat tumors by immunization with identical tumor cells infected with Friend virus. J. nat. Cancer Inst., 44, 11-19.

12) Liang, W. \& Cohen, E.P. (1976) Resistance to murine leukemia in mice rejecting syngeneic somatic hybrid cells. J. Immunol., 116, 623-626.

13) Liang, W. \& Cohen, E.P. (1977 a) Resistance to murine leukemia in mice receiving simultaneous injections of syngeneic hybrid and parental neoplastic cells. J. Immunol., 118, 903-908.

14) Liang, W. \& Cohen, E.P. (1977 b) Activation of specific cellular immunity toward murine leukemia in mice rejecting syngeneic somatioc hybrid cells. J. Immunol., 119, 1054-1060.

15) Morgan, J.F., Eng, C.P., Heuchest, M.D. \& Kirk, H.D. (1970) Loss of transplantability and induction of immunoprotection by mouse ascites tumor cells in tissue culture. Proc. Soc. exp. Biol. Med. (N.Y.), 134, 305-308.

16) Parkman, R. (1974) Tumor hybrid cells: An immunotherapeutic agent. J. nat. Cancer Inst., 52, 1541-1545.

17) Prager, M.D., Baechtel, F.S., Ribble, R.J., Ludden, C.M. \& Mehta, L.M. (1974) Immunological stimulation with modified lymphoma cells in a minimally responsive tumor-host system. Cancer, 34, 3203-3209.

18) Takatsu, K., Hamaoka, T., Tominaga, A. \& Kanamasa, Y. (1980) Augmented induction of tumor-specific resistance by priming with Mycobacterium tuberculosis (TBC) and subsequent immunization with PPD-coupled syngeneic tumor cells. J. Immunol., 125, 2367-2373.

19) Toffaletti, D.L., Darrow, T.L. \& Scott, D.W. (1983) Augmentation of syngeneic tumor specific immunity by semiallogeneic cell hybrids. J. Immunol., 130, 29822986.

20) Watkins, J.F. \& Chen, L. (1969) Immunization of mice against Ehrlich ascites tumor using hamster/Ehrlich ascites tumor hybrid cell lines. Nature, 223, 1018-1022.

21) Yefenof, E., Goldapfel, M. \& Rosaline, B. (1982) Nonimmunogenic radiation-induced lymphoma: Immunity induction by a somatic cell hybrid. J . nat. Cancer Inst., 68, 841-849. 